\title{
Role of Fine Needle Aspiration Cytology in the Diagnosis of Skin and Superficial Soft Tissue Lesions: A Study of 510 Cases
}

\author{
Deri ve Yüzeyel Yumuşak Doku Lezyonlarının Tanısında İnce İğne \\ Aspirasyon Sitolojisinin Rolü: 510 Olgunun İncelenmesi
}

\author{
Abhijit BHOWMIK, Mamata Guha MALLICK (SINHA), Dilip Chandra BARMAN
}

Department of Pathology, North Bengal Medical College and Hospital, SILIGURI, INDIA

\begin{abstract}
Objective: Diseases of the skin and superficial subcutaneous soft tissues present with a wide array of lesions ranging from nonspecific dermatoses and inflammatory lesions to frank neoplasms. Though cytopathology is an excellent diagnostic tool in routine dermatologic practice, studies relating to histopathological and cytological correlation are sparse. The aim of this study was to analyze the concordance rate between cytological and histopathological diagnosis of skin and superficial soft tissue lesions.

Material and Method: We retrospectively studied 510 consecutive fine needle aspiration cytology findings of cases from North Bengal Medical College and Hospital and correlated their diagnoses based upon cytological and histopathological grounds.

Results: Out of the 510 cases studied, 253 were non neoplastic lesions and 257 were neoplastic. A high degree of concordance was observed (100\% for malignant and $96.15 \%$ for benign lesions) when these two diagnostic modalities were compared. Histopathological correlation was possible in all malignant, 52/189 (27.51\%) of benign and 27/253 (10.67\%) of non-neoplastic lesions. Sensitivity and specificity of diagnoses were $95.31 \%$ and $97.6 \%$, respectively.

Conclusion: It can be safely concluded that fine needle aspiration cytology is a rapid, reliable and fairly accurate tool for initial triage and treatment of skin and superficial soft tissue lesions.
\end{abstract}

Key Words: Skin, Soft tissue, Cytology, Fine needle aspiration cytology

\begin{abstract}
ÖZ
Amaç: Deri ve yüzeyel subkutan yumuşak doku hastalıkları, nonspesifik dermatozlar ve iltihabi lezyonlardan neoplastik hastalıklara kadar değişen lezyonlar dizisi şeklinde prezente olur. Sitopatoloji, dermatoloji uygulamalarında mükemmel bir tanısal araç olmasına rağmen histopatoloji ve sitoloji korelasyonuna ilişkin çalışma azdır. Çalışmanın amacı deri ve yüzeyel yumuşak doku lezyonlarında sitolojik ve histopatolojik tanı uyumluluk oranlarının analiz edilmesidir.
\end{abstract}

Gereçve Yöntem: North Bengal Medical Hastanesinde değerlendirilen 510 olgunun ince iğne aspirasyon sitoloji bulguları retrospektif olarak değerlendirildi. Sitolojik ve histopatolojik tanıların korelayonu araştırıldi.

Bulgular: 510 vakanın 253 tanesi non-neoplastik, 257 tanesi neoplastik lezyondu. İki tanı yöntemi karşılaştırıldığında yüksek derecede uyum (malign lezyonlar için \%100 ve benign lezyonlar için \%96,15) gözlendi. Histopatolojik korelasyon tüm malign lezyonlarda mümkünken, 189 benign lezyondan 52 tanesi $(\% 27,512)$ ve 253 nonneoplastik lezyonun 27 tanesinde $(\% 10,67)$ korelasyon saptand. Tanıların duyarlılık ve özgüllüğü sırasıyla \%95,31 ve \% 97,6 idi.

Sonuç: İnce iğne aspirasyon sitolojisinin, deri ve yüzeyel yumuşak lezyonlarının ilk triyaj ve tedavisinda hızlı, güvenilir ve oldukça doğru bir yöntem olduğu sonucuna varılmıştır.

Anahtar Sözcükler: Deri, Yumuşak doku, Sitoloji, İnce iğne aspirasyon sitolojisi

\section{INTRODUCTION}

Various types of diseases are encountered in the skin and superficial soft tissues of the subcutis, ranging from nonspecific dermatoses and inflammatory processes to neoplastic conditions. Though cytopathology is an excellent diagnostic tool in routine dermatologic practice (1), studies relating to histopathological and cytological correlation are sparse.

(Turk Patoloji Derg 2015, 31:200-205)

Received : 07.05.2015 Accepted : 18.08.2015
The common difficulties encountered in cytological diagnosis of primary soft tissue neoplasms are their overlapping cytomorphological features, heterogeneity in some of the mass lesions and the increased recognition of borderline (intermediate) lesions (2).

Correspondence: Abhijit BHOWMIK

Department of Pathology, North Bengal Medical College and Hospital, SILIGURI, INDIA

E-mail: abhijitbhowmik@gmail.com Phone: +91904 6959830 


\section{MATERIALS and METHODS}

A total of 510 patients who underwent fine needle aspiration (FNA) for evaluation of various skin and superficial soft tissue lesions during the time period from July 2011 to February 2013 were included in the study. A detailed history of the patients was taken and physical examination findings were recorded.

FNA was performed for diagnosis in all cases. Skin scraping was done for superficial ulcers and ulcerated tumors. Tissue biopsy samples were obtained for 147 patients (28.82\%). Excisional, incisional and punch biopsies were done for histopathological examination in $78.23 \%, 7.48 \%$ and $14.29 \%$ of the patients, respectively. Under aseptic precautions, fine needle aspirations were performed using a 21 gauge needle by palpation by pathologists. For most of the cases a single pass well sufficed. For larger lesions, 2 or 3 separate passes were made. Cytological smears were stained with Hematoxylin-Eosin (H\&E) and Leishman-Giemsa for all cases. Ziehl-Neelsen (ZN) staining was performed for 13 cases. Histologic sections were routinely stained with the H\&E stain. Concordance rates between cytological and histopathological diagnosis were analyzed.

The study was approved by the Institutional Ethics Committee.

\section{RESULTS}

Out of the 510 patients studied, 263 patients (51.56\%) were male and 247 (48.44\%) were female. The youngest patient was 2 years old, the oldest being 68 years (Table I). There were 253 non neoplastic lesions and 257 neoplastic. The

Table I : Distribution of patients by age and sex

\begin{tabular}{|l|c|c|c|c|c|}
\hline Sex & No. of cases & $\mathbf{0 - 2 0}$ & $\mathbf{2 1 - 4 0}$ & $\mathbf{4 1 - 6 0}$ & $>\mathbf{6 0}$ \\
\hline Male & 263 & 43 & 89 & 96 & 35 \\
\hline Female & 247 & 47 & 82 & 88 & 30 \\
\hline Total & 510 & 90 & 171 & 184 & 65 \\
\hline
\end{tabular}

Table II: Distribution of benign neoplasms

\begin{tabular}{|l|c|c|}
\hline Type & No. of cases & \% \\
\hline Lipoma & 145 & $76.71 \%$ \\
\hline Benign spindle cell neoplasms & 27 & $14.28 \%$ \\
\hline Vascular lesions & 6 & $3.17 \%$ \\
\hline Benign adnexal lesions & 3 & $1.58 \%$ \\
\hline Nodular fasciitis & 5 & $2.64 \%$ \\
\hline Chondroid syringoma & 3 & $1.58 \%$ \\
\hline
\end{tabular}

majority of the neoplastic lesions were benign (189 cases (73.54\%)) and only 68 (26.46\%) cases were malignant.

Epidermal inclusion cyst (EIC) was the most frequently encountered non neoplastic lesion (135 cases 53.35\%). Other common lesions were acute suppurative lesions (65 cases $25.69 \%$ ), ganglion ( 21 cases $8.92 \%$ ) and granulomatous lesions (28 cases $11.06 \%$ ). Three cases of calcinosis cutis and a single case of soft tissue filariasis were noted (Figure 1). Out of the 13 cases reported as granulomatous lesion, 10 showed acid fast bacilli in $\mathrm{ZN}$ smears.

Among the benign neoplasms, lipoma was the predominant lesion (76.71\%). Other common lesions were benign spindle cell neoplasms (14.28\%) and vascular lesions (3.17\%). We found a few cases of neurofibroma, schwannoma and benign fibrous histiocytoma that where cytologically diagnosed as benign spindle cell lesion. We came across 3 cases of benign adnexal lesion among which one was diagnosed as pilomatrixoma (Figure 2). The other two could not be specifically typed but both were histologically diagnosed as pilomatrixoma. An erroneous diagnosis of EIC was given in 2 cases but later they were histologically confirmed to be pilomatrixoma (Table II).

There were 68 malignant tumors with an age range of 2-65 years. Among the malignant tumors, squamous cell carcinoma was the most common (69.11\%) followed by malignant spindle cell lesion (11.76\%) (Table III).

The youngest of our cases was a 2-year-old boy who presented with a swelling in the left upper eyelid and was diagnosed as embryonal rhabdomyosarcoma (Figure

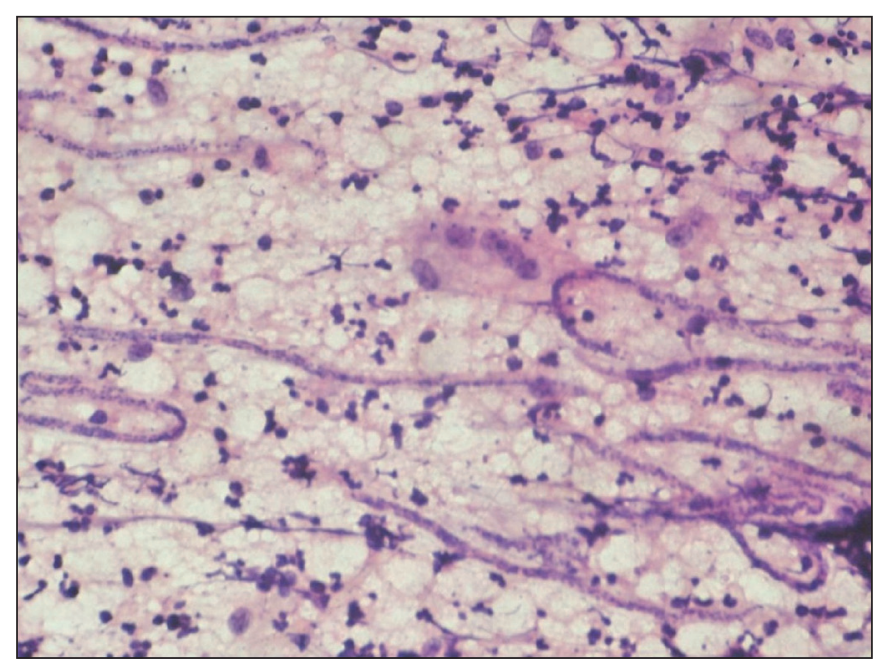

Figure 1: Smear showing adult filarial worms and a giant cell on a background of mixed inflammatory reaction (Leishman-Giemsa; $\mathrm{x} 40$ ). 


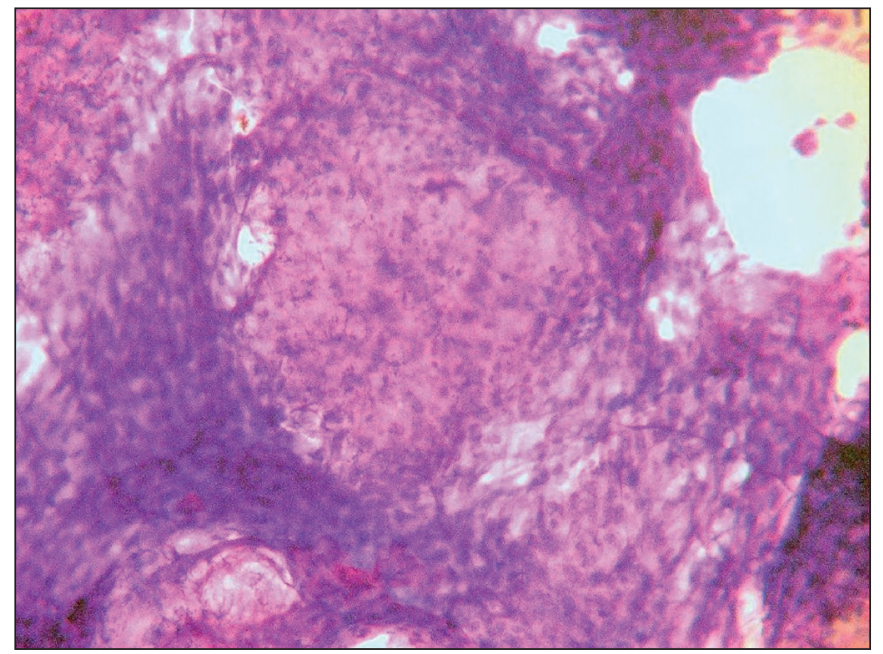

Figure 2: Smear from pilomatrixoma showing clusters of basaloid cells and scattered squamous cells on a background of calcification and amorphous material (Leishman-Giemsa; x40).

$3 \mathrm{~A}, \mathrm{~B})$. Out of the 8 cases reported as malignant spindle cell lesions, 3 were provisionally diagnosed as MPNST out of which 2 were confirmed histopathologically and the other was finally diagnosed as monophasic synovial sarcoma (Figure 4A,B). Among the other 5 cases, 3 were finally diagnosed as fibrosarcoma and 2 as angiosarcoma. Specific typing could therefore be done in just $25 \%$ of the cases for these type of lesions.

One rare case of extraskeletal plasmacytoma was reported, developing in the scalp of a 6-year-old boy and is a very unusual site for this neoplasm (Figure 5). The smears
Table III: Distribution of malignant neoplasms

\begin{tabular}{|l|c|c|}
\hline Type & $\begin{array}{c}\text { No. of } \\
\text { cases }\end{array}$ & $\%$ \\
\hline Squamous cell carcinoma & 47 & $69.11 \%$ \\
\hline Malignant spindle cell lesion & 8 & $11.76 \%$ \\
\hline Metastatic ductal carcinoma of breast & 5 & $7.35 \%$ \\
\hline Malignant melanoma & 4 & $5.88 \%$ \\
\hline Embryonal rhabdomyosarcoma & 2 & $2.94 \%$ \\
\hline Meibomian carcinoma & 1 & $1.47 \%$ \\
\hline Extraskeletal plasmacytoma & 1 & $1.47 \%$ \\
\hline
\end{tabular}

from the 4 cases of malignant melanoma that presented as pigmented cutaneous nodular lesions demonstrated pleomorphic melanocytes having atypical hyperchromatic nuclei and intracytoplasmic melanin pigment (Figure 6A,B).

Histopathological correlation was possible in all malignant, $52 / 189(27.51 \%)$ of benign and 27/253 (10.67\%) nonneoplastic lesions. Sensitivity and specificity of the diagnoses were $95.31 \%$ and $97.6 \%$, respectively. The concordance between cytological and histological diagnosis was noticed in all the malignant (100\%) and 50/52 (96.15\%) of benign lesions.

\section{DISCUSSION}

In the current era where 'the needle is preceding the scalpel' as surgical tissue biopsy becomes increasingly expensive, it seems practical to discuss the role and scope of FNAC in diagnosing skin and soft tissue tumors (3).
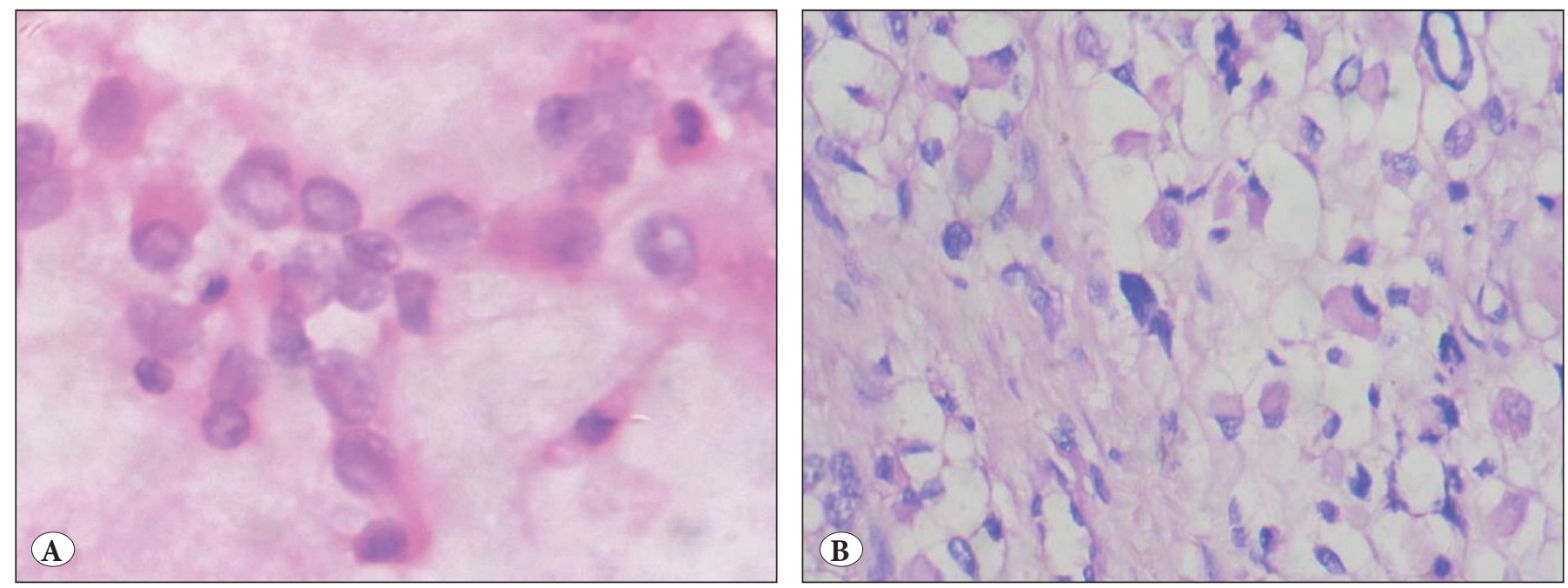

Figure 3: A) Smear from embryonal rhabdomyosarcoma showing loose clusters of small and large pleomorphic cells. Smaller cells have high N:C ratio. Few cells with eccentric placed nuclei and dense cytoplasm are noted. Occasional tadpole shaped cells are also seen (H\&E; $\mathrm{x} 40$ ). B) Section from embryonal rhabdomyosarcoma showing tumor cells in sheets and nests. Small cells with hyperchromatic round to oval nuclei and larger cells with eccentric nuclei and dense eosinophilic cytoplasm are noted (H\&E; x40). 

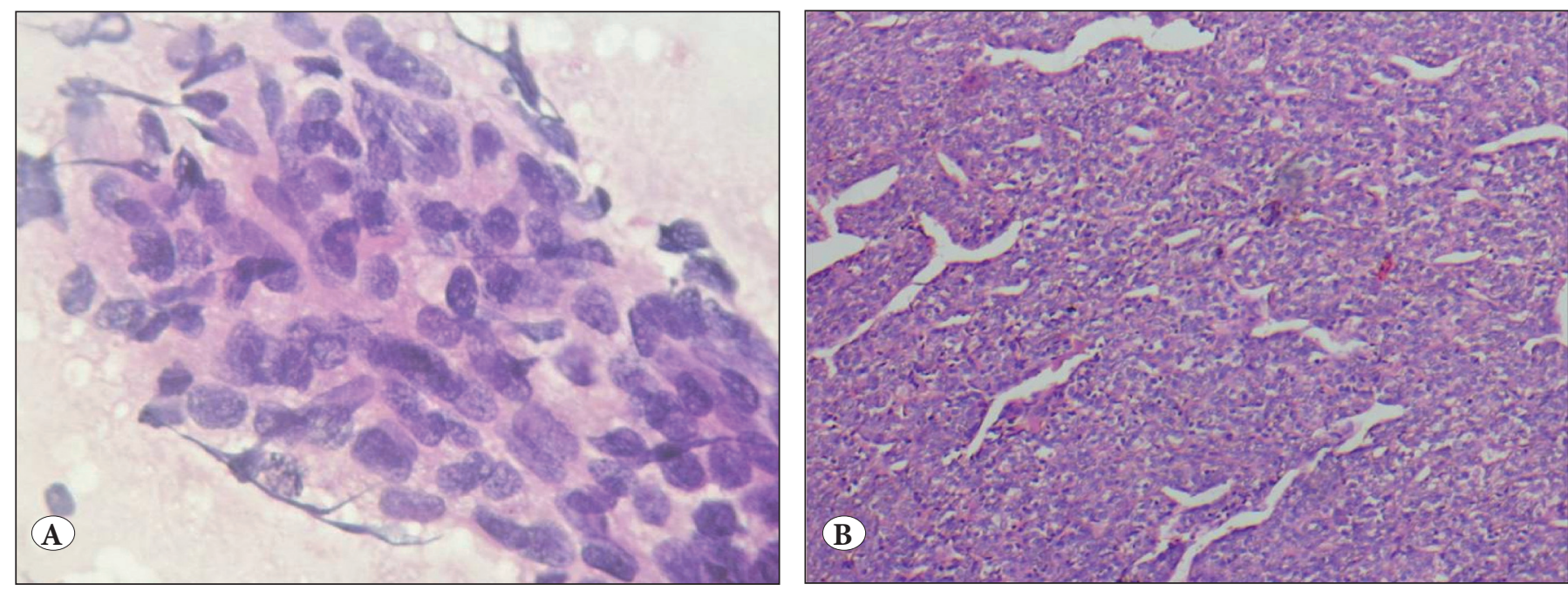

Figure 4: A) Smear from malignant spindle cell lesion showing hypercellularity with clusters of moderately pleomorphic spindle cells. Cells have spindly, elongated nuclei, coarse chromatin and scanty to moderate cytoplasm. Mitotic figures were noted in other portion of the smear (Leishman-Giemsa; x40). B) Sections from monophasic synovial sarcoma show sheets of spindle cells having oval to spindly nuclei and scanty inapparent cytoplasm particularly in the more cellular areas. A hemangiopericytomatous pattern is evident in a few areas $(\mathrm{H} \& \mathrm{E} ; \mathrm{x} 10)$.

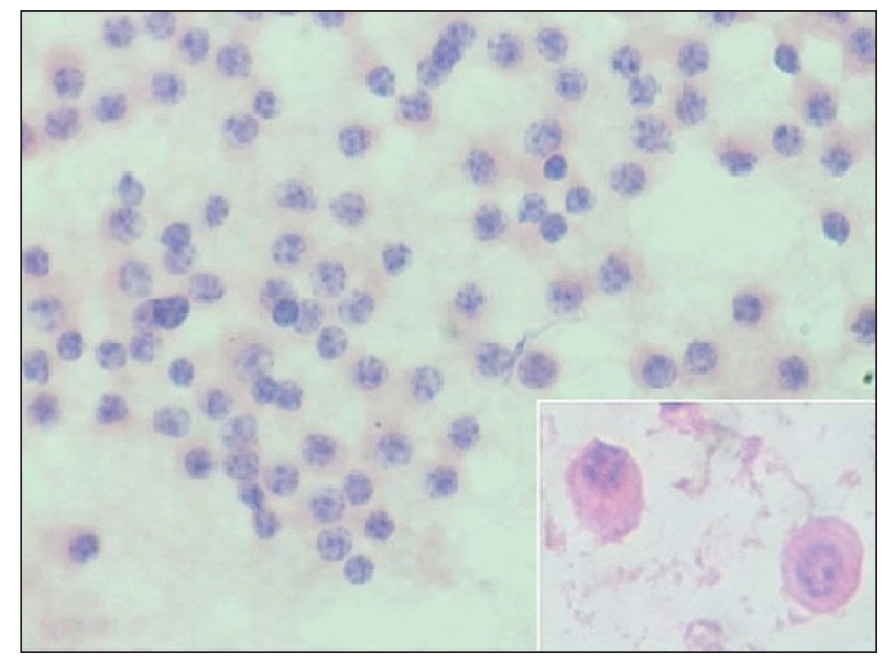

Figure 5: Cellular smear from extraskeletal plasmacytoma showing diffuse population of plasmacytoid cells. Cells with eccentrically-placed nuclei having characteristic clock-face chromatin is shown in the inset (H\&E; $\mathrm{x} 40)$.

In our experience, histopathological correlation was possible in all malignant and $27.51 \%$ of benign neoplasms whereas the sensitivity and specificity of diagnosis was $95.31 \%$ and $97.6 \%$, respectively.

It was seen that biopsy provided complete tissue details for accurate diagnosis; however, diagnosis takes a longer time as compared to the early diagnosis provided by cytology. Yet it may not be readily available, as is evident from this study, where 137 cases reported as benign neoplasm in the cytopathological report did not comply with a request for biopsy.

The concordance between cytological and histological diagnosis was noticed in all the malignant $(100 \%)$ and 50/52 (96.15\%) of benign lesions. Thus, a considerably high degree of concordance was achieved among cytological and histological modalities of diagnosis.

Only two cases of pilomatrixoma were misdiagnosed as epidermal inclusion cysts. The main reasons behind the erroneous diagnosis was the selective sampling of squamous cells. These findings are in concordance with a previous study by Bansal et al. (4).

Lipoma was the predominant benign tumor $(81.34 \%)$ in our study, keeping in concordance with the study by Beg et al. (5).

The most frequent malignant neoplasm encountered in our study was squamous cell carcinoma which is at par with the published literature (6). Eight cases were reported as malignant spindle cell lesion cytologically. Among them 3 were provisionally diagnosed as MPNST out of which 2 were confirmed histopathologically and the other was finally diagnosed as monophasic synovial sarcoma. It may often be difficult to differentiate MPNST from monophasic synovial sarcoma (particularly the fibrous variant) only on morphological grounds without recourse to immunohistochemical or cytogenetic studies, which was also observed by Folpe et al. $(7,8)$. 

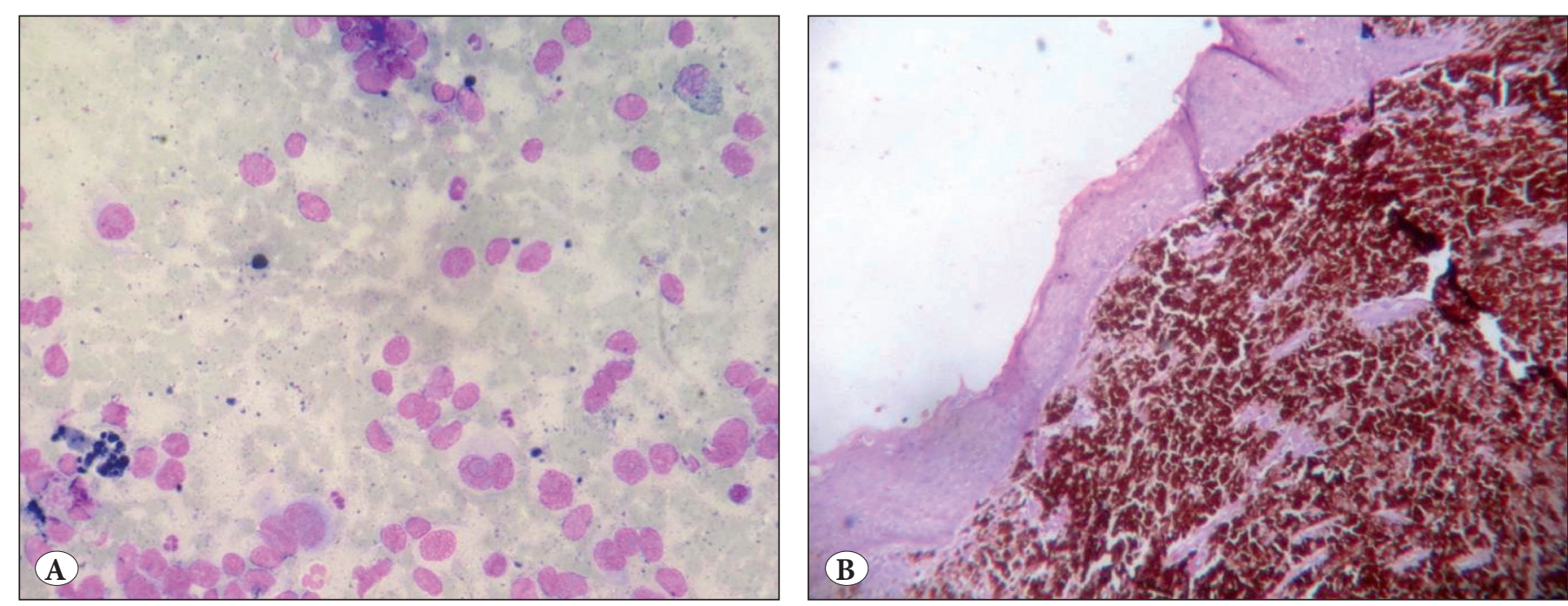

Figure 6: A) Smear from malignant melanoma showing diffuse population of pleomorphic cells. Cells have eccentrically placed hyperchromatic pleomorphic nuclei with intranuclear inclusions, prominent nucleoli and abundant dense cytoplasm with intracytoplasmic pigment. Few binucleated cells are noted (Leishman-Giemsa; x40). B) Section from malignant melanoma showing diffuse infiltration of epidermis and dermis by anaplastic melanocytes. Cells are highly pleomorphic having atypical hyperchromatic nuclei and intracytoplasmic melanin pigment (H\&E; x10).

A histological diagnosis of fibrosarcoma was made in 3 cases and angiosarcoma in 2 cases. Thus, specific typing could be done in just $25 \%$ of the cases of these malignant spindle cell lesions. Exact cytological typing for these types of lesions were possible in $23.33 \%$ cases in a study by Rekhi et al. (3).

The aspirate from the 2 cases of embryonal rhabdomyosarcoma showed moderately pleomorphic small and large cells admixed with typical rhabdomyoblast like cells. Histological confirmation was obtained.

Interestingly, we also encountered a single case of extraskeletal plasmacytoma at an unusual site that revealed diffuse population of plasmacytoid cells. The smears from the 4 cases of malignant melanoma that presented as pigmented cutaneous nodular lesions did not pose any diagnostic difficulties. Five of our cases had a past history of ductal carcinoma of the breast and they presented with metastatic nodular deposits in the overlying skin that was evident cytologically.

FNAC proved to be of great value in the investigation of clinically suspected metastatic lesions, keeping at par with the studies undertaken by Wong et al., Rekhi et al. and Spitz et al. $(3,9,10)$.

In conclusion, FNAC is a rapid, reliable and fairly accurate tool for initial triage and treatment of skin and superficial soft tissue lesions. However, it should be correlated with the clinical history, and histopathological and immunohistochemical studies wherever necessary for the final diagnosis and management.

\section{CONFLICT OF INTEREST}

The authors declare no conflict of interests.

\section{REFERENCES}

1. Sabir F, Aziz M, Afroz N, Amin SS. Clinical and cytohistopathological evaluation of skin lesions with special reference to bullous lesions. Indian J Pathol Microbiol. 2010;53:41-6.

2. Geisinger KR, Abdul-Karim FW. Fine needle aspiration biopsies of soft tissue tumors. In: Weiss SW, Goldblum JR, editors. Enzinger and Weiss's soft tissue tumors. 4th ed. Missouri: Mosby; 2001. 147.

3. Rekhi B, Gorad BD, Kakade AC, Chinoy R. Scope of FNAC in the diagnosis of soft tissue tumors-A study from a tertiary cancer referral center in India. Cytojournal. 2007;4:20.

4. Bansal C, Handa U, Mohan H. Fine needle aspiration cytology of pilomatrixoma. J Cytol. 2011;28:1-6.

5. Beg S, Vasenwala SM, Haider N, Ahmad SS, Maheshwari V, Khan M. A comparison of cytological and histopathological findings and role of immunostains in the diagnosis of soft tissue tumors. J Cytol. 2012;29:125-30.

6. Orell SR, Sterrett GF, Whitaker D. Skin and subcutis. In: Orell SR, Sterrett GF, Whitaker D, editors. Fine needle aspiration cytology. 4th ed. New Delhi: Elsevier Limited; 2005. 395.

7. Folpe AL, Schmidt RA, Chapman D, Gown AM. Poorly differentiated synovial sarcoma: Immunohistochemical distinction from primitive neuroectodermal tumors and highgrade malignant peripheral nerve sheath tumors. Am J Surg Pathol. 1998;22:673-82. 
8. Måns Åkerman. Benign and malignant soft tissue tumors. In: Gray W, McKee GT editors. Diagnostic cytopathology. 2nd ed. London, UK: Churchill Livingstone; 2003. 907-8.

9. Wong NL, Dl F. Fine needle aspiration cytology of myxoid lesions of soft tissues: A study of 24 cases. Zhonghua Bing Li XueZa Zhi. 2007;36:619-23.

10. Spitz DJ, Reddy V, Selvaggi SM, Kluskens L, Green L, Gattuso P. Fine needle aspiration of scalp lesions. Diagn Cytopathol. 2000;23:35-8. 